\title{
The Effect of Reading Comprehension Skills on The Ability of Solving Word Problems to Fourth Grade Students of Public Elementary Schools in Alian Subdistrict in Academic Year of 2019/2020
}

\author{
Rizki Noviana. ${ }^{1}$, Joharman. ${ }^{2}$, Muh. Chamdani ${ }^{3}$ \\ PGSD, FKIP, Universitas Sebelas Maret, Indonesia \\ rizki_noviana@student.uns.ac.id
}

\section{Article History}

accepted 01/10/2020

approved 01/11/2020

published 01/12/2020

\begin{abstract}
The study aimed to prove the effect of reading comprehension skills on the ability of solving word problems and to determine the effect of reading comprehension skills on the ability of solving word problems to fourth grade students of public elementary schools in Alian Sub-district in academic year of 2019/2020. It was quantitative research with correlation method. The sampling method was cluster random sampling with the help of Statistical Product and Service Solution (SPSS) application version 16. From data analysis, correlation coefficient of reading comprehension skills on the ability of solving word problems was 0,610 and it was strong correlation. Reading comprehension skills affected the ability of solving word problems by $37.2 \%$. It concludes that there is positive effect of reading comprehension skills on the ability of solving word problems. It means that the higher students' reading comprehension skills, the higher students' word problems solving ability.
\end{abstract}

Keywords: reading comprehension, solving word problems

\begin{abstract}
Abstrak
Penelitian ini bertujuan untuk menguji ada tidaknya pengaruh positif keterampilan membaca pemahaman terhadap kemampuan menyelesaikan soal cerita dan menentukan persentase pengaruh keterampilan membaca pemahaman terhadap kemampuan menyelesaikan soal cerita siswa kelas IV SDN se-Kecamatan Alian tahun ajaran 2019/2020. Penelitian ini merupakan penelitian kuantitatif dengan metode korelasional. Pengambilan sampel dilakukan dengan teknik cluster random sampling. Peneliti menggunakan aplikasi SPSS versi 16 untuk menganalisis data. Dari analisis data didapatkan koefisien korelasi variabel keterampilan membaca pemahaman terhadap kemampuan menyelesaikan soal cerita sebesar 0,610 dan termasuk tingkat korelasi kuat. Keterampilan membaca pemahaman memberikan pengaruh terhadap kemampuan menyelesaikan soal cerita sebesar $37,2 \%$. Berdasarkan analisis dan pembahasan hasil penelitian dapat disimpulkan bahwa terdapat pengaruh positif keterampilan membaca pemahaman terhadap kemampuan menyelesaikan soal cerita, yang menunjukkan semakin tinggi keterampilan membaca pemahaman siswa, maka semakin tinggi pula kemampuan menyelesaikan soal cerita siswa.
\end{abstract}

Kata kunci: membaca pemahaman, menyelesaikan soal cerita 


\section{PENDAHULUAN}

Pendidikan dasar memberikan bekal kemampuan dasar baca tulis hitung, dan keterampilan dasar yang bermanfaat bagi siswa sesuai tingkat perkembangannya. Praditha, Kusmariatni, dan Japa (2017:2) menyatakan bahwa salah satu keterampilan dasar yang harus dikuasai siswa sekolah dasar adalah keterampilan berbahasa. Bahasa merupakan aspek yang sangat penting dalam berinteraksi. Keterampilan ini digunakan seseorang untuk dapat melakukan komunikasi. Salah satu pelajaran bahasa di sekolah dasar yang paling mendasar adalah membaca. Membaca adalah suatu proses yang dilakukan serta dipergunakan oleh pembaca untuk memperoleh pesan yang hendak disampaikan oleh penulis melalui media kata-kata/bahasa tulis (Tarigan, 2015:7).

Membaca merupakan salah satu keterampilan berbahasa yang tidak dapat lepas dari kehidupan sehari-hari. Melalui membaca, siswa dapat memperoleh pengetahuan, ilmu, dan informasi sebanyak-banyaknya. Membaca dapat membantu keberhasilan siswa di berbagai bidang studi. Membaca pemahaman merupakan salah satu jenis keterampilan membaca yang dapat membantu siswa belajar.

Keterampilan membaca pemahaman adalah keterampilan untuk memahami makna suatu bacaan yang merupakan keterampilan yang harus dikuasai siswa. Dalman (2013:87) menyatakan bahwa membaca pemahaman adalah membaca secara kognitif (membaca untuk memahami). Dalam membaca pemahaman, pembaca dituntut mampu memahami isi bacaan. Keterampilan membaca pemahaman yang dimiliki oleh seseorang didapat dari proses belajar yang dilakukan dengan tekun dan terlatih.

Keterampilan membaca pemahaman selalu digunakan dalam setiap pembelajaran. Keterampilan ini digunakan siswa untuk memahami berbagai jenis bacaan. Berdasarkan wawancara dengan guru kelas IV di salah satu SDN di Kecamatan Alian pada tanggal 9 November 2019, beliau menyebutkan bahwa siswa kelas IV masih kurang menguasai keterampilan membaca pemahaman. Siswa kurang konsentrasi saat membaca sehingga pemahaman terhadap bacaan masih kurang. Siswa juga terlihat beberapa kali harus kembali mengulangi membaca bacaan yang sudah dibacanya. Hal ini menyebabkan siswa kesulitan dalam menyelesaikan tugas yang berhubungan dengan bacaan. Padahal keterampilan ini diperlukan di semua mata pelajaran tak terkecuali matematika. Matematika mengharuskan siswa menguasai keterampilan membaca pemahaman, karena matematika berisi permasalahan sehari-hari yang disajikan dalam bentuk soal cerita. Dalam mengerjakan tugas matematika tentang soal cerita, masih banyak siswa yang kesulitan menerjemahkan bacaan ke dalam kalimat matematika. Siswa juga merasa kesulitan untuk menentukan operasi hitung yang digunakan untuk menyelesaikan permasalahan.

Menurut Winarni dan Harmini (2012:122), soal cerita adalah soal matematika yang diungkapkan atau dinyatakan dengan kata-kata atau kalimat-kalimat dalam bentuk cerita yang dikaitkan dengan kehidupan sehari-hari. Soal cerita berisi wacana permasalahan yang harus dipecahkan melalui penalaran siswa sehingga dapat mengembangkan pola pikir logis dan kritis dalam menyelesaikan masalah. Soal cerita disusun menggunakan kalimat yang sederhana, bermakna, dan menggambarkan suatu permasalahan matematika yang terjadi dalam kehidupan sehari-hari. Disini keterampilan membaca pemahaman menjadi modal untuk dapat mengubah soal cerita menjadi kalimat matematika.

Operasi hitung bilangan cacah merupakan salah satu materi pokok dalam mata pelajaran matematika yang penyajian soal pemecahan masalahnya cenderung berbentuk soal cerita. Siswa diharapkan dapat menyelesaikan soal tersebut dengan cara yang tepat. Penyelesaian yang dikaji dalam materi operasi hitung bilangan cacah terbagi atas beberapa sub materi, di antaranya operasi hitung penjumlahan, pengurangan, perkalian, pembagian, dan operasi hitung campuran. Permasalahan 
dalam soal cerita dapat diselesaikan dengan perencanaan yang matang dan langkahlangkah yang runtut seperti yang telah dikemukakan oleh Polya (Winarni dan Harmini, 2012:124-126) yaitu 1) pemahaman terhadap masalah, 2) perencanaan pemecahan masalah, 3) melaksanakan perencanaan pemecahan masalah, dan 4) melihat kembali kelengkapan pemecahan masalah.

Menyelesaikan suatu soal cerita bukan hanya untuk mendapatkan jawaban akhir saja. Tetapi yang terpenting siswa mengetahui dan memahami proses atau langkah untuk menyelesaikan permasalahan tersebut. Tentu tidak mudah untuk menyelesaikan masalah dalam soal cerita. Oleh karena itu diperlukan keterampilan membaca pemahaman.

Keterampilan membaca pemahaman memiliki peran penting dalam mengembangkan keterampilan memecahkan masalah (Nicolas dan Emata, 2018:40). Seseorang tidak dapat menyelesaikan masalah kecuali orang tersebut sepenuhnya memahami konsep dan situasi yang diberikan. Keterampilan membaca pemahaman dan kemampuan memecahkan masalah selalu berjalan beriringan. Keterampilan membaca pemahaman harus dikembangkan oleh siswa untuk memahami informasi sehingga dapat memberikan solusi terhadap masalah yang diberikan dalam soal cerita.

Terdapat berbagai kesulitan yang dialami siswa dalam menyelesaikan masalah dalam soal cerita (Tarigan dalam Widyanto, 2017:3) yaitu 1) siswa tidak mengetahui makna dari soal, 2) siswa menjawab pertanyaan dengan singkat, 3) siswa tidak mengetahui makna informasi yang diketahui maupun permasalahan yang ditanyakan dalam soal.

Auzar (2017:146) berpendapat bahwa "the ability to understand the language of mathematical word problems is related to the ability to read for comprehension because both require the ability to comprehend a text." Kemampuan untuk memahami bahasa dan memecahkan masalah saling berhubungan dengan kemampuan membaca pemahaman karena keduanya dibutuhkan dalam memahami bacaan. Seperti yang telah kita ketahui bahwa soal cerita berisi permasalahan tentang matematika yang berkaitan dengan kehidupan sehari-hari. Keterampilan membaca pemahaman diperlukan untuk memahami masalah dan mencari penyelesaian terhadap masalah tersebut.

Berdasarkan penjelasan di atas, permasalahan dalam penelitian ini adalah: (1) apakah keterampilan membaca pemahaman berpengaruh positif terhadap kemampuan menyelesaikan soal cerita siswa kelas IV SDN se-kecamatan Alian Tahun Ajaran 2019/2020?; (2) seberapa besar pengaruh keterampilan membaca pemahaman terhadap kemampuan menyelesaikan soal cerita siswa kelas IV SDN se-kecamatan Alian tahun ajaran 2019/2020?.

Tujuan dari penelitian ini yaitu : (1) menguji ada tidaknya pengaruh positif keterampilan membaca pemahaman terhadap kemampuan menyelesaikan soal cerita tentang operasi hitung bilangan cacah pada siswa kelas IV SDN se-kecamatan Alian tahun ajaran 2019/2020; (2) menentukan persentase pengaruh keterampilan membaca pemahaman terhadap kemampuan menyelesaikan soal cerita pada siswa kelas IV SDN se-kecamatan Alian tahun ajaran 2019/2020.

\section{METODE}

Desain penelitian yang digunakan yaitu penelitian kuantitatif dengan metode korelasi. Purwanto (2012:177) menyatakan penelitian korelasi adalah penelitian yang melibatkan hubungan satu atau lebih variabel dengan satu atau lebih variabel lain.

Populasi pada penelitian ini yaitu siswa kelas IV SDN di Kecamatan Alian sebanyak 851 siswa dengan sampel sebanyak 274 siswa. Pengambilan sampel dilakukan dengan teknik cluster random sampling. Pengambilan sampel dilakukan secara random menggunakan aplikasi SPSS. 
Teknik pengumpulan data yang digunakan dalam penelitian ini yaitu tes. Tes yang digunakan untuk mengukur keterampilan membaca pemahaman siswa adalah tes berbentuk pilihan ganda. Indikator yang digunakan untuk mengukur keterampilan membaca pemahaman pada penelitian ini adalah 1) menjawab pertanyaan atas materi yang dibaca dalam bacaan, 2) menentukan kalimat/gagasan utama dalam suatu wacana, 3) menentukan pokok pikiran/makna paragraf, serta 4) menentukan kesimpulan dari suatu paragraf. Sedangkan untuk mengukur kemampuan menyelesaikan soal cerita peneliti menggunakan tes soal cerita Matematika tentang operasi hitung bilangan cacah yang berbentuk uraian. Materi yang diujikan untuk mengukur kemampuan menyelesaikan soal cerita pada penelitian ini adalah tentang operasi hitung bilangan cacah yang memuat operasi hitung penjumlahan, pengurangan, perkalian, pembagian, dan operasi hitung campuran. Sebelum digunakan, tes tersebut diuji validitasnya terlebih dahulu. Pengujian validitas dilakukan di dua SDN di Kecamatan Alian.

Uji prasyarat data yang digunakan adalah uji normalitas menggunakan uji liliefors, dan uji linieritas. Uji hipotesis yang digunakan adalah uji korelasi sederhana dan sumbangan efektif. Uji korelasi sederhana digunakan untuk menguji ada tidaknya pengaruh keterampilan membaca pemahaman terhadap kemampuan menyelesaikan soal cerita. Uji sumbangan efektif digunakan untuk mencari besarnya sumbangan variabel keterampilan membaca pemahaman terhadap kemampuan menyelesaikan soal cerita.

\section{HASIL DAN PEMBAHASAN}

Penelitian dilakukan dengan memberikan tes membaca pemahaman dan soal cerita kepada siswa kelas IV di SDN yang menjadi sampel penelitian. Data yang telah diperoleh di lapangan kemudian diolah menggunakan aplikasi SPSS. Uji prasyarat pada penelitian ini ada dua macam yaitu uji normalitas dan uji linieritas. Hasil pengujian ini adalah syarat untuk melakukan pengujian hipotesis penelitian. Uji prasyarat data pada penelitian ini telah terpenuhi yaitu data berdistribusi normal dan linear.

Dari hasil uji normalitas variabel keterampilan membaca pemahaman menghasilkan nilai sig $=0,213$ (sig $>0,05)$, sedangkan variabel kemampuan menyelesaikan soal cerita menghasilkan nilai sig 0,745 (sig $>0,05)$. Dari nilai sig tersebut menunjukkan bahwa kedua variabel tersebut berdistribusi normal. Hasil uji linieritas keterampilan membaca pemahaman terhadap kemampuan menyelesaikan soal cerita menghasilkan nilai sig $=0,439(\mathrm{sig}>0,05)$. Hal ini menunjukkan bahwa keterampilan membaca pemahaman dan kemampuan menyelesaikan soal cerita memiliki hubungan yang linier.

Setelah uji prasyarat data terpenuhi, selanjutnya dilakukan uji hipotesis. Dari hasil analisis menggunakan uji korelasi pearson product moment, diketahui bahwa terdapat pengaruh positif keterampilan membaca pemahaman terhadap kemampuan menyelesaikan soal cerita dengan nilai $r=0,610$, dan sig $=0,000(\operatorname{sig}<0,000)$. Dari hasil uji korelasi tersebut maka hipotesis yang menyatakan terdapat pengaruh positif keterampilan membaca pemahaman terhadap kemampuan menyelesaikan soal cerita siswa kelas IV SDN se-kecamatan Alian tahun ajaran 2019/2020 dapat diterima dan termasuk kategori kuat. Berdasarkan hasil penelitian tersebut dapat disimpulkan bahwa semakin tinggi tingkat keterampilan membaca pemahaman siswa, maka akan semakin tinggi tingkat kemampuan menyelesaikan soal cerita. Begitu pun sebaliknya, semakin rendah tingkat keterampilan membaca pemahaman, maka akan semakin rendah pula kemampuan menyelesaikan soal cerita. Oleh karena itu keterampilan membaca pemahaman berperan penting dalam menyelesaikan soal cerita, karena keterampilan ini digunakan untuk memahami bacaan. Siswa yang mempunyai keterampilan membaca pemahaman yang baik akan lebih mudah memahami sesuatu hal yang disajikan secara 
tertulis dan begitupun sebaliknya. Keterampilan membaca ini digunakan di semua mata pelajaran, tak terkecuali matematika, khususnya pada soal cerita.

Diterimanya hipotesis ini sesuai dengan penelitian yang dilakukan oleh Andanik dan Fitrianawati (2018:44) yang menyatakan bahwa kemampuan membaca pemahaman berpengaruh positif dan signifikan terhadap kemampuan pemecahan soal cerita Matematika siswa kelas V SD Muhammadiyah Ambarbinangun dan menghasilkan korelasi pearson sebesar 0,746 dan termasuk dalam derajat hubungan korelasi kuat.

Hasil penelitian ini juga sejalan dengan penelitian yang dilakukan Rohmah (2015: 57) yang menyatakan bahwa ada hubungan yang positif dan signifikan antara membaca pemahaman dengan kemampuan menyelesaikan soal cerita matematika, dengan $r$ hitung 0,632 lebih besar dari $r$ tabel 0,213 $(0,632>0,213)$ termasuk dalam tingkat hubungan kuat.

Selain itu hasil penelitian ini juga diperkuat oleh penelitian Setiyoko (2016: 69) yang menyatakan bahwa keterampilan membaca pemahaman berpengaruh signifikan terhadap kemampuan menyelesaikan soal cerita matematika. Artinya semakin baik keterampilan membaca pemahaman siswa maka semakin baik pula kemampuan menyelesaikan soal cerita matematikanya.

Sumbangan keterampilan membaca pemahaman terhadap kemampuan menyelesaikan soal cerita dapat dicari menggunakan rumus yang dikemukakan oleh Winarsunu (2015:185). Berdasarkan perhitungan sumbangan keterampilan membaca pemahaman terhadap kemampuan menyelesaikan soal cerita, didapatkan hasil yang menyatakan bahwa keterampilan membaca pemahaman berpengaruh terhadap kemampuan menyelesaikan soal cerita sebesar $37,2 \%$ dan sisanya sebesar $62,8 \%$ dipengaruhi oleh faktor lain yang tidak diteliti dalam penelitian ini. Hal tersebut sejalan dengan penelitian Handayani (2017: 327) yang menyatakan bahwa keterampilan membaca pemahaman bukan satu-satunya variabel atau faktor yang menyebabkan siswa mampu menyelesaikan permasalahan dalam soal cerita, tetapi terdapat faktorfaktor lain yang mempengaruhi, seperti pengalaman, motivasi, dan keterampilan berfikir kritis. Berdasarkan uraian tersebut, dapat disimpulkan bahwa hasil penelitian ini telah sesuai dengan teori yang ada dan didukung pula dengan hasil penelitian yang relevan.

\section{SIMPULAN}

Berdasarkan hasil penelitian dan pembahasan, didapatkan kesimpulan bahwa keterampilan membaca pemahaman berpengaruh positif terhadap kemampuan menyelesaikan soal cerita siswa kelas IV SDN se-Kecamatan Alian dengan tingkat korelasi kuat yaitu 0,610. Artinya, semakin tinggi tingkat keterampilan membaca pemahaman maka akan semakin tinggi pula kemampuan menyelesaikan soal cerita. Persentase pengaruh keterampilan membaca pemahaman terhadap kemampuan menyelesaikan soal cerita yaitu $37,2 \%$ sedangkan sisanya dipengaruhi oleh faktor lain seperti pengalaman, motivasi, dan keterampilan berpikir kritis. Oleh karena itu, keterampilan membaca pemahaman penting untuk ditingkatkan saat pelajaran sehingga diharapkan kemampuan menyelesaikan soal cerita juga meningkat. Hasil penelitian ini dapat menjadi rekomendasi bagi guru maupun calon guru dalam upaya peningkatan kualitas proses pembelajaran, khususnya dalam pembelajaran membaca pemahaman. Selain memotivasi siswa untuk giat membaca, guru dapat memberikan banyak latihan membaca agar siswa dapat membiasakan diri untuk membaca, memahami bacaan, dan menambah kosakata. 


\section{DAFTAR PUSTAKA}

Andanik, R.T. dan Fitrianawati, M. (2018). Pengaruh Keterampilan Membaca Pemahaman terhadap Kemampuan Pemecahan Soal Cerita Matematika Peserta Didik Kelas V Sekolah Dasar. Jurnal Fundamental Pendidikan Dasar, 2(2), 40-46.

Auzar. (2017). The Relationships of Reading Comprehension Ability with the Ability to Understand The Questions of Mathematical Word Problems. Mediterranean Journal of Social Sciences, 8(4), 145-151.

Dalman. (2013). Keterampilan Membaca. Jakarta:Rajawali Pers.

Handayani, K. (2017). Analisis Faktor-faktor yang Mempengaruhi Kemampuan Pemecahan Masalah Soal Cerita Matematika. Prosiding Seminar Nasional Matematika Peran Alumni Matematika dalam Membangun Jejaring Kerja dan Peningkatan Kualitas Pendidikan, hlm. 325-330. Medan: Fakultas Matematika Universitas Negeri Medan.

Nicolas, C. A. T. \& Emata, C. Y. (2018). An Integrative Approach through Reading Comprehension to Enhance Problem-Solving Skills of Grade 7 Mathematics Students. International Journal of Innovation in Science and Mathematics Education, 26(3), 40-64.

Praditha, M. A., Kusmariatni, N., Japa, G. N. (2017). Hubungan Antara Kemampuan Membaca Pemahaman dengan Menyelesaikan Soal Cerita Matematika Siswa Kelas IV. e-Journal PGSD Universitas Pendidikan Ganesha Mimbar PGSD, 5(2), 1-10.

Purwanto. (2012). Metodologi Penelitian Kuantitatif untuk Psikologi dan Pendidikan. Yogyakarta:Pustaka Pelajar.

Rohmah, F.N. (2015). Hubungan antara Membaca Pemahaman dengan Kemampuan Menyelesaikan Soal Cerita Matematika pada Siswa Kelas IV SD se-Gugus Karangmojo III Gunung Kidul. Skripsi, Universitas Negeri Yogyakarta, Yogyakarta.

Setiyoko. (2016). Pengaruh Keterampilan Membaca Pemahaman terhadap Kemampuan Menyelesaikan Soal Cerita Matematika Siswa Kelas IV Sekolah Dasar Gugus IV Kecamatan Pengasih. Skripsi, Universitas Negeri Yogyakarta, Yogyakarta.

Tarigan, H.G. (2015). Membaca sebagai Suatu Keterampilan Berbahasa. Bandung:Angkasa.

Widyanto, S. (2017). Pengaruh Kemampuan Membaca Pemahaman terhadap Kemampuan Menyelesaikan Soal Cerita Matematika Siswa Kelas V. Jurnal Pendidikan Guru Sekolah Dasar, 3(6), 257-268.

Winarni, E.S. \& Harmini, S. (2012). Matematika untuk PGSD. Bandung:PT Remaja Rosdakarya.

Winarsunu, T. (2015). Statistik dalam Penelitian Psikologi dan Pendidikan. Malang:UMM Press. 